\title{
Review
}

Edward J. Cowan \& Lizanne Henderson, eds., A History of Everyday Life in Medieval Scotland, 1000-1600. A History of Everyday Life in Scotland. Edinburgh: Edinburgh University Press, 2011. Pp. 319. ISBN 978-0-7486-2157-6. £24.99.

A History of Everyday Life in Medieval Scotland is a fresh and inviting book, even though social history is, at this point, well established. Scottish social history developed in the eighteenth century; it was soon, however, largely overshadowed by historians performing political revision. Its revival in the later twentieth-century was timely, but the subject matter took time to develop into a robust field. New social histories, including the medieval volume of the Everyday Life in Scotland series, have provided more focus on issues like marriage and the family.

This recent publication has demonstrated that there is now a large group of committed social historians whose interests lie in fleshing out the daily lives of their subjects. In this volume, historians address questions of environment, leisure, piety, and family life in medieval Scotland. Scotland's medieval history is so coloured by politics that the everyday can often be obscured. The authors in this volume make use of a wide variety of sources to provide answers to the question, what was life like for the common folk in medieval Scotland?

Everyday Life is both an excellent introductory history for the casual student as well as a well-rounded work for an academic audience. Every chapter causes the reader to consider the many facets of life in the Middle Ages and is both engaging and thought-provoking. Elizabeth Ewan's 
chapter on "Sights, Sounds, and Smells in the Medieval Town" draws the reader into the world of a medieval urban Scot. Discussions of clothing, buildings, and occupations in Edinburgh, Aberdeen, and Dundee, among other burghs, bring the urban world to life. Ted Cowan rounds out this discussion, describing life in early Glasgow. Chapters on gaming and material culture highlight a wide range of artefacts, from the famed Lewis Chessmen to lesser-known hoards.

David Sellar's chapter on the family argues for competing, parallel models of marriage in Scotland: specifically, secular Celtic marriage and canonical marriage. This overview of family life is long overdue and condenses much of the detailed information on the family into a single, accessible source for the basic methods of forming marriage and dissolving marriage. He also discusses the many roles of the medieval family.

Four of the chapters discuss new approaches to old documents, using sources such as the Bruce, the Wallace, Viking sagas, and late medieval chronicles to reveal new information about daily life. Fiona Watson's chapter on the "Landscape and People" shines an interdisciplinary light on this material, looking at not only the land itself but also its impact on society in how farmers lived, what foods people ate, and its effect on politics.

The final two papers in this volume bring the discussion to the darker side of Scotland. Richard Oram writes about death and disease in the medieval world, focusing especially on leprosy, plague, and syphilis. He describes men and women preparing for death and the afterlife. Lizanne Henderson writes about the origins of the witch hunts in the late sixteenth-century realm, and about the toll that the culture of magic could take on a populace for whom witchcraft accusations were not part of their daily lives. 
Everyday Life does not pretend to be a comprehensive social history, and there are subjects that deserve much more attention. For instance, because the chapters are brief overviews of each topic, there is an overall sense of geographical and chronological unity where, in fact, differences were just as common. In many ways, the work aims to inspire further research on such a broad subject area. It has succeeded in these goals, as a well-crafted introduction to social history and the world of medieval Scotland.

\section{Heather Parker}

University of Guelph 